\title{
Sediment Loads in the Ventura River Basin, Ventura County, California, 1969-81
}

By Barry R. Hill and Christopher E. McConaughy

\section{U.S. GEOLOGICAL SURVEY}

Water-Resources Investigations Report 88-4149

Prepared in cooperation with the

CALIFORNIA DEPARTMENT OF BOATING AND WATERWAYS

d.

Sacramento, California 1988 
DEPARTMENT OF THE INTERIOR

DONALD PAUL HODEL, Secretary

U.S. GEOLOGICAL SURVEY

Dallas L. Peck, Director

For additional information write to:

District Chief

U.S. Geological Survey

Federal Building, Room W-2234

2800 Cottage Way

Sacramento, CA 95825
Copies of this report

can be purchased from:

U.S. Geological Survey

Books and Open-File Reports Section

Federal Center, Building 810

Box 25425

Denver, CO 80225 


\section{CONTENTS}

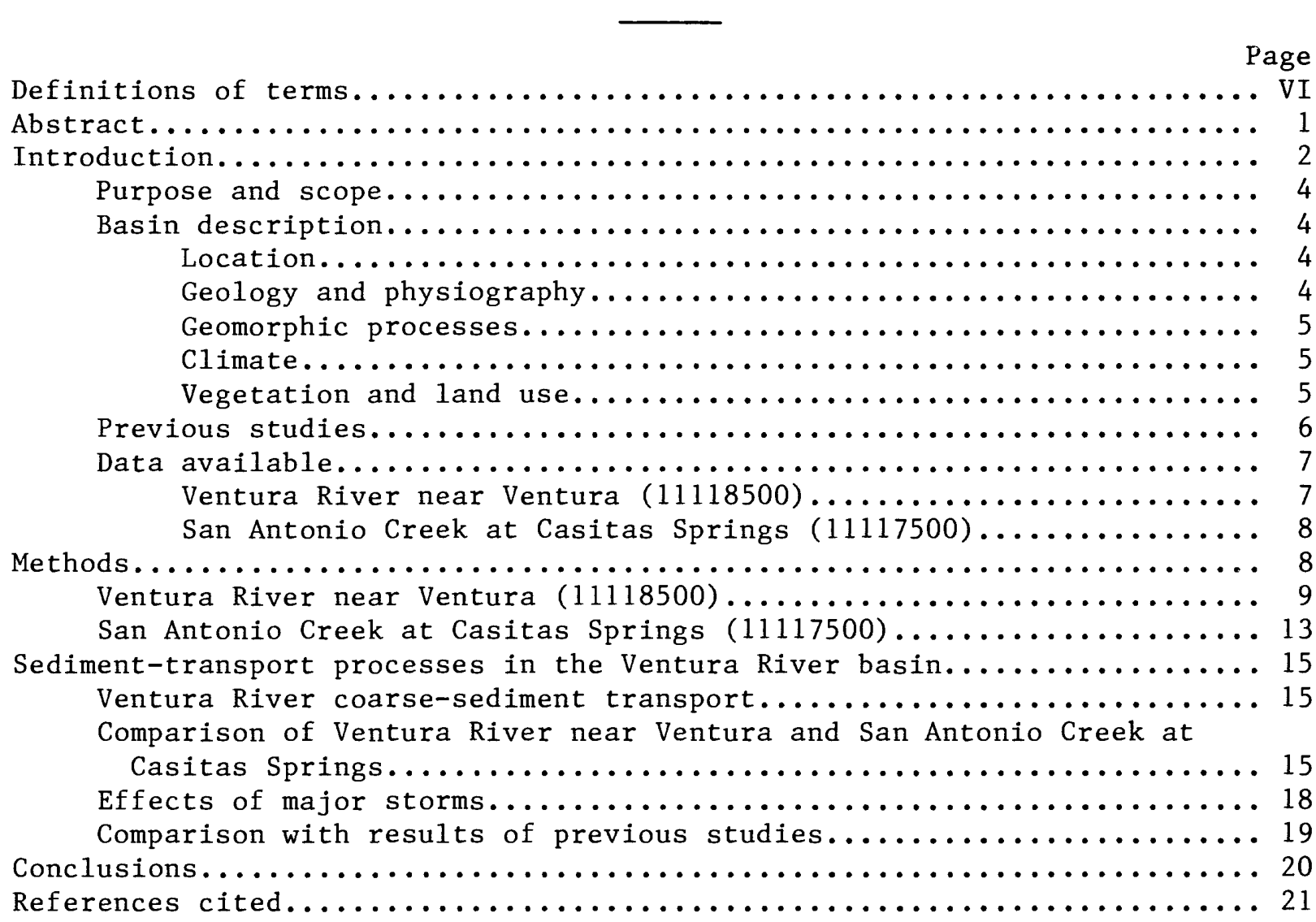




\section{ILLUSTRATIONS}

Figure 1. Map showing study area and location of gaging stations and

Page sediment-sampling sites......................... 3

2. Bedload-transport curve, Ventura River near Ventura (11118500).. 11

3. Concentration curves for total-suspended and coarse-suspended sediment, Ventura River near Ventura (11118500), 1969-73,

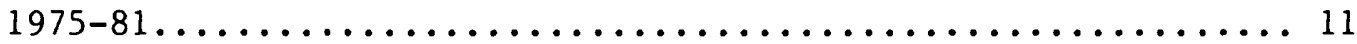

4. Bedload-transport curve, San Antonio Creek at Casitas Springs

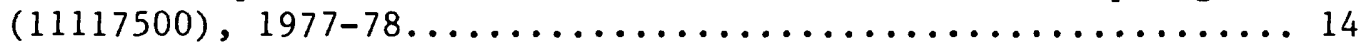

5. Concentration curves for total-suspended sediment and coarse-suspended sediment, San Antonio Creek at Casitas

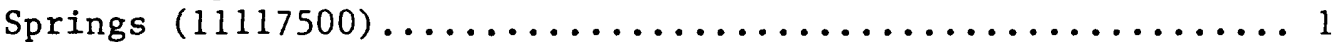

\section{TABLES}

Table 1. Reservoirs and diversion structures in the Ventura River basin

Page

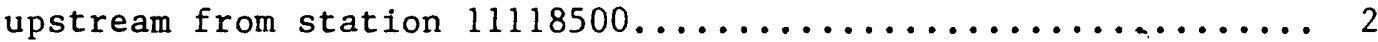

2. Results from previous studies of average sediment yield in and adjacent to the Ventura River basin................... 6

3. Particle-size distribution of surficial bed material, Ventura

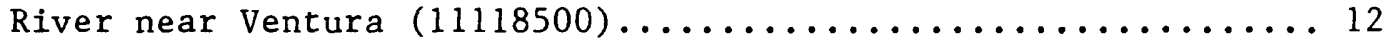

4. Particle-size distribution of surficial bed material, San Antonio

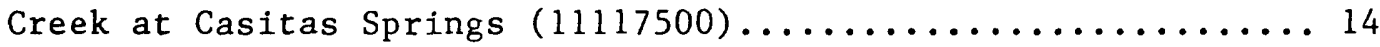

5. Estimated sediment load at Ventura River near Ventura (11118500),

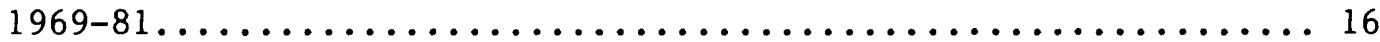

6. Estimated sediment load at San Antonio Creek at Casitas Springs

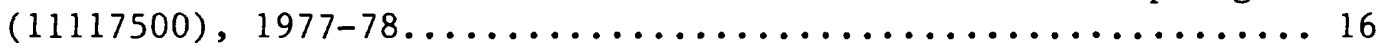

7. Sediment transport at Ventura River near Ventura (11118500) during major storm periods, $1969-81 \ldots \ldots \ldots \ldots \ldots \ldots \ldots \ldots \ldots$ 


\section{CONVERSION FACTORS}

The inch-pound system of units is used in this report. For readers who prefer metric (International System) units, the conversion factors for the terms used in this report are listed below:

\begin{tabular}{|c|c|c|}
\hline Multiply inch-pound unit & $\underline{B y}$ & To obtain metric unit \\
\hline acre-foot (acre-ft) & $1,2 \frac{5}{33} .0$ & cubic meter \\
\hline $\begin{array}{l}\text { acre-foot per square mile } \\
\left(\text { acre-ft } / \mathrm{mi}^{2}\right)\end{array}$ & 476.1 & $\begin{array}{l}\text { cubic meter per } \\
\text { square kilometer }\end{array}$ \\
\hline $\begin{array}{l}\text { acre-foot per square mile } \\
\text { per year }\left[\left(\text { acre-ft/mi }{ }^{2}\right) / y r\right]\end{array}$ & 476.1 & $\begin{array}{l}\text { cubic meter per } \\
\text { square kilometer } \\
\text { per annum }\end{array}$ \\
\hline $\begin{array}{l}\text { foot (ft) } \\
\text { cubic foot per second }\left(\mathrm{ft}^{3} / \mathrm{s}\right)\end{array}$ & $\begin{array}{l}0.3048 \\
0.02832\end{array}$ & $\begin{array}{l}\text { meter } \\
\text { cubic meter per } \\
\text { second }\end{array}$ \\
\hline $\begin{array}{l}\text { inch (in.) } \\
\text { pound per cubic foot }\left(1 \mathrm{~b} / \mathrm{ft}^{3}\right)\end{array}$ & $\begin{array}{l}25.4 \\
16.02\end{array}$ & $\begin{array}{l}\text { millimeter } \\
\text { kilogram per cubic } \\
\text { meter }\end{array}$ \\
\hline mile (mi) & 1.609 & kilometer \\
\hline square mile $\left(\mathrm{mi}^{2}\right)$ & 2.590 & square kilometer \\
\hline short ton (ton) & 0.9072 & megagram \\
\hline short ton per day (ton/d). & 0.9072 & megagram per day \\
\hline short ton per year (ton/yr) & 0.9072 & megagram per annum \\
\hline $\begin{array}{l}\text { short ton per square mile } \\
\text { per year }\left[\left(\operatorname{ton} / \mathrm{mi}^{2}\right) / \mathrm{yr}\right]\end{array}$ & 0.5638 & $\begin{array}{l}\text { megagram per square } \\
\text { kilometer per annum }\end{array}$ \\
\hline cubic yard $\left(\mathrm{yd}^{3}\right)$ & 0.7646 & cubic meter \\
\hline
\end{tabular}

Particle size is given in millimeters. To convert from millimeters to inches, multiply value in millimeters by 0.03937 .

Degrees Fahrenheit $\left({ }^{\circ} \mathrm{F}\right)$ is converted to degrees Celsius $\left({ }^{\circ} \mathrm{C}\right)$ by using the formula:

$$
\text { Temp. }{ }^{\circ} \mathrm{C}=\left(\text { temp. }{ }^{\circ} \mathrm{F}-32\right) 1.8 \text {. }
$$

Abbreviations and symbols used:

mg/L (milligrams per liter)

$<$ (less than)

$>$ (greater than) 


\section{DEFINITIONS OF TERMS}

Terms used in this report adhere to the definitions of the U.S. Geological Survey (1977) except where otherwise noted.

Bedload is the material moving on or near the streambed by rolling, sliding, and sometimes making brief excursions into the flow a few diameters above the bed. of time.

Bedload discharge is the quantity of bedload passing a transect in a unit

Bed material is the sediment mixture of which the streambed is composed.

Cubic foot per second-day (cfs-day) is the volume of water represented by a flow of 1 cubic foot per second for 24 hours. It is equivalent to 86,400 cubic feet.

Coarse-sediment discharge is that fraction of the total-sediment discharge composed of particles equal to or larger than $0.062 \mathrm{~mm}$ intermediate grain diameter. It usually includes all the sediment moving as bedload and part of the suspended sediment.

Coarse-suspended-sediment discharge is that fraction of suspendedsediment discharge composed of particles equal to or larger than $0.062 \mathrm{~mm}$ intermediate grain diameter.

Measured suspended-sediment discharge is the part of the suspendedsediment discharge that can be computed from the total water discharge and mean sediment concentration in the depth actually sampled with the suspendedsediment sampling equipment. Measured suspended-sediment discharge is published annually in the U.S. Geological Survey Water-Data Reports and is generally considered to be the suspended-sediment discharge, expressed in tons per day.

Sediment is solid material that is derived mostly from disintegrated rocks and is transported by, suspended in, or deposited from water; it includes chemical and biochemical precipitates and decomposed organic material such as humus. The quantity, characteristics, and cause of occurrence of sediment in streams are influenced by environmental factors. Some major factors are degree of slope, length of slope, soil characteristics, land usage, and quantity and intensity of precipitation.

Sediment concentration is the mass of dry solids divided by the volume of water and is expressed in milligrams per liter.

Sediment discharge is the rate at which the dry mass of sediment passes a section of a stream, or is the quantity of sediment, as measured by dry mass or volume, that is discharged in a given time. 
Sediment load is the sediment in suspension and (or) transport. Load usually is expressed in terms of mass or volume (for example, grams, tons, or cubic feet).

Sediment-transport curve is the curve that defines the average relation between the rate of sediment discharge and rate of streamflow. Transport curves may be classified according to either the period of the basic data that define the curve or the kind of sediment discharge that a curve represents (Colby, 1956).

Sediment yield is the quantity of sediment, total or suspended, that is transported from or produced per unit area. Sediment yield usually is expressed as a mass or volume per unit area and time (for example, tons per square mile per year) (U.S. Geological Survey, 1986).

Streamflow is the mixture of water, sediment, and solutes discharged by a natural channel (Porterfield, 1980).

Suspended sediment is sediment that is moved in suspension in water and is maintained in suspension by the upward components of turbulent currents or by colloidal suspension.

Total-sediment discharge is the sum of the suspended-sediment discharge and the bedload discharge, as measured by dry mass or volume, that is discharged during a given time (Colby and Hembree, 1955).

Water year is the 12-month period that starts October 1 and ends September 30; it is designated by the calendar year in which it ends. In this report, all yearly designations refer to water year, except as otherwise noted. 
SEDIMENT LOADS IN THE VENTURA RIVER BASIN, VENTURA COUNTY, CALIFORNIA, 1969-81

By Barry R. Hill and Christopher E. McConaughy

\section{ABSTRACT}

To estimate the replenishment of beach sands by fluvial transport from the Ventura River, sediment data collected during a 12-year period (1969-81) were used to develop relations between bedload and coarse-suspended-sediment loads and streamflow. These relations were used to calculate coarse- and total-sediment loads from the Ventura River, and to assess the effects of major storms on sediment transport. Sediment data collected on an unregulated tributary over a 2-year period were used to assess effects of dam construction on sediment loads and to identify major sediment-source areas in the Ventura basin.

Total-sediment load from the Ventura River for the 12 years of data collection was $12,800,000$ tons, of which $5,100,000$ tons, or 40 percent, consisted of coarse material potentially available for replenishment of beach sands. Suspended-sediment transport was the dominant process supplying sediment to the coast, accounting for more than 98 percent of the total-sediment load and 96 percent of the coarse-sediment load. Higher streamflows carried proportionately more coarse-suspended sediment than low flows. Major storm events transported more than 96 percent of both total- and coarse-sediment annual loads during three high-flow years. The sequence of storm events may influence storm-period sediment transport, as sediment removed rapidly during high flows is gradually replenished by hillslope processes.

The sediment yield of the unregulated part of the basin was higher than that of the regulated part. Consideration of the trap efficiencies of reservoirs in the basin, however, indicates that actual yields may be highest in areas affected by impoundments. 


\section{INTRODUCTION}

The beaches of southern California are maintained by the erosion of coastal drainage basins and subsequent fluvial transport of sediment to the coastline (Rice and others, 1976). Coarse sediments deposited at the mouths of coastal rivers are reworked by wave action and transported by littoral currents, providing material for the beaches.

In the Ventura River basin (fig. 1), the natural flux of sediment to the coast has been altered by developments such as dams and diversions. Since 1948, reservoirs have been constructed on two principal tributaries of the Ventura River (table 1). These reservoirs trap substantial quantities of coarse sediment (Lustig, 1965; Scott and Williams, 1978). Although the net delivery of sediment to the coastline has decreased, the 1ittoral-drift process has not. The reduction in sediment supply has raised concerns about present beach erosion and effects of future developments on the supply of beach sand. To evaluate the potential for increased beach erosion under present and future water-management operations, an assessment of sediment-transport relations in the Ventura River basin is needed. The analysis of sediment data presented in this report was completed in cooperation with the California Department of Boating and Waterways.

Table 1.--Reservoirs and diversion structures in the Ventura River basin upstream from station 11118500

[Storage capacity is given as of 1968. Trap efficiency is given as calculated by the storage capacity-drainage area method (Brune, 1953); --, not determined]

\begin{tabular}{|c|c|c|c|c|c|}
\hline $\begin{array}{l}\text { Reservoir } \\
\text { or } \\
\text { structure }\end{array}$ & $\begin{array}{l}\text { Year of } \\
\text { construc- } \\
\text { tion }\end{array}$ & $\begin{array}{c}\text { Storage } \\
\text { capacity, } \\
\text { in acre- } \\
\text { feet }\end{array}$ & $\begin{array}{l}\text { Drainage } \\
\text { area, in } \\
\text { square } \\
\text { miles }\end{array}$ & $\begin{array}{l}\quad \text { Trap } \\
\text { efficiency, } \\
\text { in percent }\end{array}$ & Remarks \\
\hline $\begin{array}{l}\text { Matilija } \\
\quad \text { Reservoir }\end{array}$ & 1948 & 2,500 & 55 & 82 & $\begin{array}{l}\text { Original capac- } \\
\text { ity was } 7,000 \\
\text { acre-feet. }\end{array}$ \\
\hline $\begin{array}{l}\text { Robles-Casitas } \\
\text { Diversion }\end{array}$ & 1959 & 19 & $\begin{array}{l}76 \\
\text { (21 below } \\
\text { Matilija } \\
\text { Reservoir) }\end{array}$ & -- & $\begin{array}{l}\text { Diverts maximum } \\
\text { of } 500 \text { cubic } \\
\text { feet per sec- } \\
\text { ond; not } \\
\text { operated dur- } \\
\text { ing high } \\
\text { flows. }\end{array}$ \\
\hline Lake Casitas & 1959 & 254,000 & 39 & 99 & \\
\hline
\end{tabular}




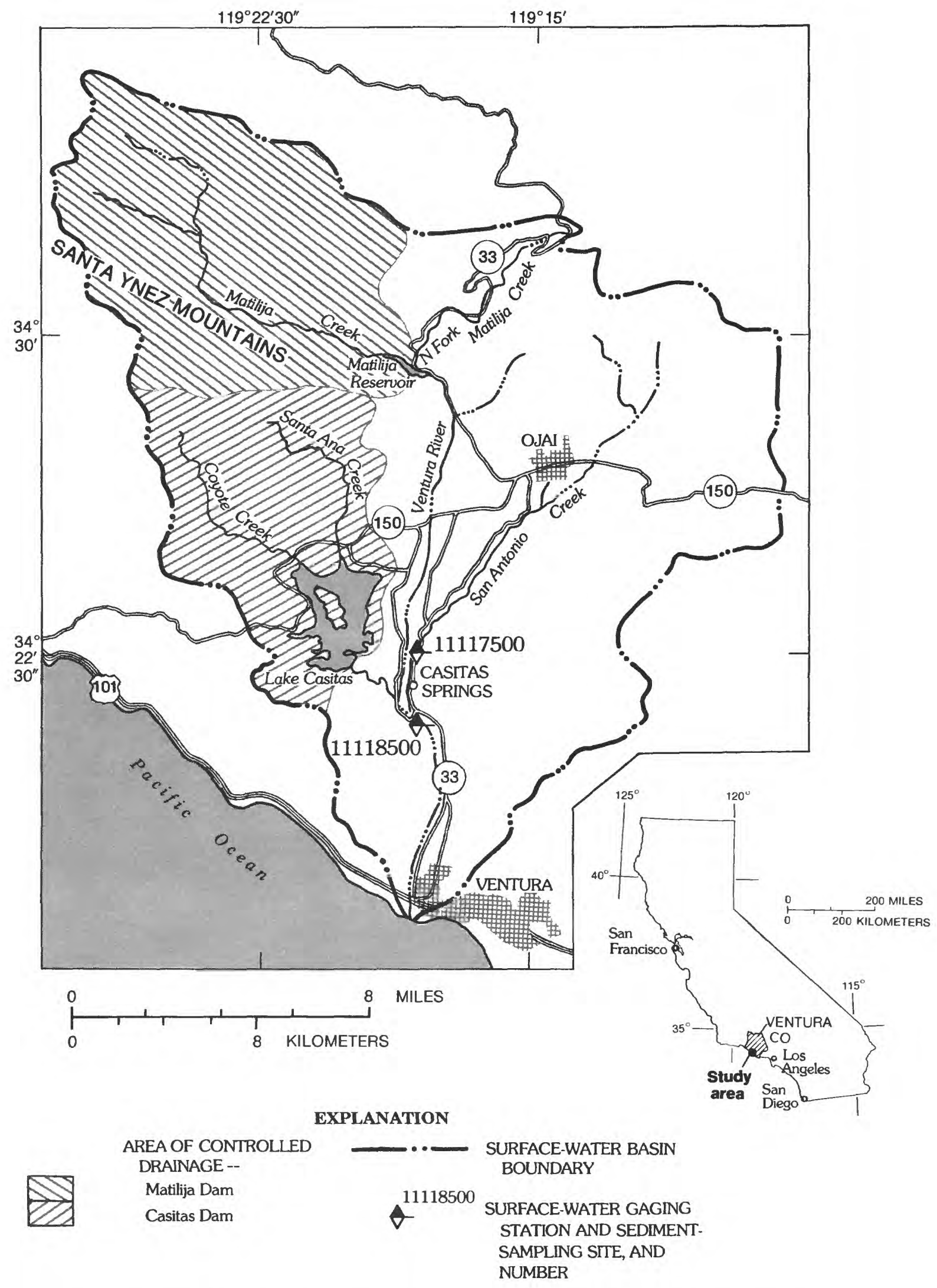

FIGURE 1.-- Study area and location of gaging stations and sediment-sampling sites. 


\section{Purpose and Scope}

This report describes the results of a study to estimate the loads of coarse and total sediment from the Ventura River basin under existing conditions of flow regulation and land use. Comparisons were made between results of this study and other recent studies of sediment transport in coastal southern California, and between sediment-transport characteristics of regulated and unregulated parts of the basin. Effects of major storms were evaluated, and possible sources of coarse sediment were considered in the context of geomorphic processes.

The analyses of sediment transport were made by using published and unpublished data previously collected by the U.S. Geological Survey. Sediment and streamflow data collected at two stations in the basin between 1969 and 1981 were used to define empirical relations between streamflow and the transport of bedload and coarse-suspended sediment. By use of these relations, annual values of coarse-suspended sediment load, bedload, and total sediment load were calculated.

\section{Basin Description}

Location

The Ventura River basin, in southern California, is about 60 miles westnorthwest of Los Angeles (fig. 1). The drainage area of the Ventura River is $226 \mathrm{mi}^{2}$. The river originates in the Santa Ynez Mountains and flows generally southward for approximately 15 miles from the confluence of Matilija and North Fork Matilija Creeks to its mouth near the city of Ventura.

Geology and Physiography

Uplands in the basin are underlain primarily by sedimentary rocks consisting of Tertiary sandstones, shales, and limestones; valley bottoms contain fills of Quaternary alluvium (Putnam, 1942). Active tectonism and contrasts in erodibility of rock types have produced a rugged topography, with narrow valleys and steep streambeds in the upland sections (Putnam, 1942). Nearly 45 percent of the basin may be classified as mountainous, 40 percent as foothill, and 15 percent as valley area (U.S. Bureau of Reclamation, 1954). Basin relief is about 6,000 feet. 
Geomorphic processes contributing sediment to channel systems in southern California coastal watersheds include sheet erosion (Lustig, 1965) and several forms of mass wasting. Mass-wasting processes of particular significance in the Ventura River basin are dry sliding (Scott and Williams, 1978), slumping and earthflows (Putnam, 1942), and debris flows (Scott and Williams, 1978). Scott and Williams (1978) described a conceptual model of headwater-basin sediment transport in which channel infilling by dry sliding and sheet erosion during dry and moderate years alternates with channel scour by debris flows during major storms. Their conceptual model supports the finding of Anderson and others (1959) that dry-season hillslope processes contribute more sediment to channels than do fluvial processes.

The significance of channel-bed and bank erosion as a sediment source in the Ventura River basin may approach that of hillslope processes (Taylor, 1981). Lustig (1965), however, suggested that channel erosion might provide only 20 percent of the sediment yield in the nearby Castaic watershed, which has lithology similar to that of the Ventura basin over about half its area. Because alluvial channels throughout the southern California coastal mountains may be undergoing a period of entrenchment and erosion (Putnam, 1942; Scott and others, 1968; Cooke and Reeves, 1976; Scott and Williams, 1978; and Knott, 1980), channel erosion must be considered a potentially significant sediment source.

Climate

The Ventura River basin has a Mediterranean-type climate, with warm, dry summers and mild and relatively wet winters. Rainfall distribution is highly seasonal, with nearly all precipitation falling during the winter months (Cooke and Reeves, 1976). Average annual precipitation ranges from about 15 inches at the city of Ventura to as much as 30 inches in the mountains of the northern part of the basin (Rantz, 1969).

\section{Vegetation and Land Use}

Vegetation cover is primarily chaparral, with limited amounts of sagebrush, conifers, and grass (Wells and Palmer, 1982). There may have been a reduction in density of chaparral and coniferous forest during the 1ate 19th century due to overgrazing and burning (Cooke and Reeves, 1976).

Land use in the steep upland areas of the Ventura River basin is restricted to livestock grazing and recreation. Lowland areas have been affected to some degree by cultivation and urbanization. 


\section{Previous Studies}

Several previous studies have provided estimates of sediment yields in the Ventura River and adjacent basins, but these estimates are difficult to compare because of differences in methods, types and periods of data considered, and units used to report results. In particular, it is difficult to relate erosion rates reported as volumes of sediment per unit time to records of sediment that are determined as weight or mass per unit time, because estimates of bulk densities of eroded materials are not readily available. For purposes of comparison, all sediment yields reported by other authors as volumes per unit time have been converted to acre-feet per square mile per year $\left(\left(\right.\right.$ acre-ft/mi $\left.\left./ \mathrm{m}^{2}\right) / \mathrm{yr}\right)$ and are summarized in table 2 .

Table 2.--Results from previous studies of average sediment yield in and adjacent to the Ventura River basin

[Sediment yield is given in acre-feet per square mile per year]

\begin{tabular}{|c|c|c|c|c|}
\hline Studyl & $\begin{array}{c}\text { Drainage } \\
\text { basin }\end{array}$ & $\begin{array}{c}\text { Type of } \\
\text { data } \\
\text { considered }\end{array}$ & $\begin{array}{l}\text { Sediment } \\
\text { yield }\end{array}$ & Remarks \\
\hline Lustig, 1965 & Castaic & $\begin{array}{l}\text { Reservoir } \\
\quad \text { sedimentation }\end{array}$ & 1.82 & \\
\hline $\begin{array}{l}\text { Scott and others, } \\
1968\end{array}$ & $\begin{array}{l}\text { Matilija } \\
\quad \text { (Ventura) }\end{array}$ & do. & .96 & \\
\hline Do. & Piru & $\begin{array}{l}\text { Physiographic } \\
\text { characteristics }\end{array}$ & .79 & \\
\hline $\begin{array}{l}\text { Scott and Williams, } \\
1978\end{array}$ & $\begin{array}{l}\text { Ventura } \\
\text { headwaters }\end{array}$ & do. & $1.60-6.80$ & \\
\hline Knott, 1980 & $\begin{array}{l}\text { Cañada de los } \\
\text { Alamos (Piru) }\end{array}$ & do. & .26 & \\
\hline Taylor, 1981, 1983 & Ventura & $\begin{array}{l}\text { Sediment } \\
\text { discharge }\end{array}$ & 4.20 & \\
\hline \multirow{2}{*}{$\begin{array}{l}\text { California Department } \\
\text { of Navigation and } \\
\text { Ocean Development, } \\
1977\end{array}$} & \multirow[t]{2}{*}{ Ventura } & \multirow[t]{2}{*}{ do. } & .27 & $\begin{array}{l}\text { Coarse } \\
\text { sediment }\end{array}$ \\
\hline & & & .62 & $\begin{array}{l}\text { Prior to dam } \\
\text { construc- } \\
\text { tion }\end{array}$ \\
\hline
\end{tabular}

1For fu11 citations, see "References Cited" section. 
Regression analysis has been used by various authors to obtain predictive equations for sediment yields in the southern California mountains based on data obtained from basins with known rates of reservoir sedimentation. Lustig (1965) used this approach to calculate a sediment yield of 1.82 $\left(\right.$ acre-ft $/ \mathrm{mi}^{2}$ )/yr for the Castaic watershed in western Los Angeles County. Scott and others (1968) reported the average sediment yield above Matilija Reservoir (fig. 1) in the upper Ventura basin to be 0.96 (acre-ft/mi ${ }^{2}$ )/yr. Using a variety of empirical methods, these authors estimated the long-term sediment yield of the Piru Creek basin, northeast of and adjacent to the Ventura basin, to be $0.79\left(\mathrm{acre}-\mathrm{ft} / \mathrm{mi}^{2}\right) / \mathrm{yr}$. Scott and Williams (1978), in an extensive study of erosion in the southern California mountains, estimated that sediment yields resulting from the heavy storms of 1969 in the headwaters of the Ventura River ranged from 19.3 to $52.2 \mathrm{acre}-\mathrm{ft} / \mathrm{mi}^{2}$. Estimated long-term yields for this area ranged from approximately 1.6 to 6.8 (acre-ft/mi $\left.{ }^{2}\right) / y r$. Knott (1980) estimated a long-term yield of 0.26 (acre-ft/mi $\left./ \mathrm{m}^{2}\right) / \mathrm{yr}$ for the Cañada de los Alamos, a tributary of Piru Creek. Taylor (1981, 1983) calculated an upland erosion rate of $4.2\left(\mathrm{acre}-\mathrm{ft} / \mathrm{mi}^{2}\right) / \mathrm{yr}$ for the Ventura basin; of the material eroded, 20 percent was estimated to be sand size or larger.

Other investigators have considered streamflow and sediment-discharge records compiled for gaging stations in the basin. Shiller (1972) showed that the mean grain size of suspended sediment in the Ventura River during the high flows of 1969 was proportional to stream velocity, streamflow, and sediment concentration. The California Department of Navigation and Ocean Development (1977) applied the modified Einstein bedload formula (Burkham and others, 1977) to records of streamflow to obtain an estimated annual coarse-sediment yield of 0.27 (acre-ft/mi ${ }^{2}$ )/yr for the Ventura basin for 1969-75. This report included a sediment-yield estimate of 0.62 (acre-ft/mi $\left./ \mathrm{m}^{2}\right) / \mathrm{yr}$ prior to construction of dams in the basin. Brownlie and Taylor (1981) used existing suspended-sediment data and the modified Einstein formula to obtain load estimates of 2.28 million tons of coarse sediment and 8.12 million tons of total sediment for the period $1969-75$ at the Ventura River near Ventura (station 11118500).

Data Available

Ventura River near Ventura (11118500)

Records of daily streamflow at station 11118500 extend from October 1929 to the present (1984). Streamflow data for the period of this study are contained in reports by the U.S. Geological Survey (1972-75a, 1976, 1976-82). Drainage area is $188 \mathrm{mi}^{2}$. Periods of flow regulation and drainage-basin areas affected are given in table 1 , and locations of reservoirs are shown in figure 1. All existing regulation structures were operational prior to 1969; no changes in regulation occurred during the period of sediment-data collection. Average daily streamflow for $1912-13$ and $1930-82$ was $58.3 \mathrm{ft}^{3} / \mathrm{s}$. Streamflow is intermittent in most years. Maximum instantaneous streamflow was 63,600 $\mathrm{ft}^{3} / \mathrm{s}$ on February 10, 1978 . 
Sediment data were collected at station 11118500, Ventura River near Ventura, from 1969 to 1973 and from 1975 to 1981. Daily values of suspendedsediment discharge and monthly values of bedload discharge were published previously (U.S. Geological Survey, 1972-75b, 1974a, 1974b, 1976-82). Additionally, some hydraulic and particle-size data and bedload measurements made using the method of Helley and Smith (1971) (available in U.S. Geological Survey data files) were used in the computations described below. Total suspended-sediment load for the period of data collection was $12,600,000$ tons, with an average annual load of 1,050,000 tons. Minimum annual suspendedsediment load was 957 tons in 1977 and maximum annual load was 6,650,000 tons in 1969. Bedload values were computed independently for this report as described below, and previously published values were not used. No sediment data were collected in water year 1974, and all references to "period of data collection" for station 11118500 apply to water years 1969-73 and 1975-81.

\section{San Antonio Creek at Casitas Springs (11117500)}

Streamflow data at station 11117500 have been collected from October 1949 to the present. Streamflow data for the period of this study are contained in reports by the U.S. Geological Survey (1972-75a, 1976, 1976-82). Drainage area is $51 \mathrm{mi}^{2}$. Flow is unregulated above the station. Average daily streamflow for $1949-82$ was $13.2 \mathrm{ft}^{3} / \mathrm{s}$. Streamflow is intermittent in most years. Maximum instantaneous streamflow was $16,200 \mathrm{ft}^{3} / \mathrm{s}$ on January 25, 1969.

Daily suspended-sediment data were collected from October 1976 to September 1978 at station 11117500. Suspended-sediment load was 2,420 tons in 1977 and 1,390,000 tons in 1978 (U.S. Geological Survey, 1976-82). Unpublished hydraulic and particle-size data collected during streamflow measurements and sampling (available in U.S. Geological Survey data files) were used, as were bedload-discharge measurements made using the method of Helley and Smith (1971). Previously published bedload-discharge values (U.S. Geological Survey, 1976-82) were not used, for reasons discussed below.

\section{METHODS}

Because sediment discharge is related to streamflow (Guy, 1970), continuous streamflow records provide a means of estimating annual sediment load at sites where instantaneous measurements or calculations of sediment discharge have been made. The relation between sediment discharge and water discharge is commonly expressed in graphic form as an average curve on logarithmic paper. Such curves, known as sediment-transport curves, can be developed from instantaneous discharges of suspended sediment, bedload, or any sediment-size fraction for which data are available (Colby, 1956). Under some circumstances, instantaneous sediment-transport curves can be used in conjunction with average daily streamflow values as discussed by Colby (1956) to provide average daily values of sediment load. These daily values can then be summed to give estimates of annual sediment load for the type of sediment for which the transport curve was developed. 
For this report, previously collected data were used to define relations between coarse-suspended-sediment and bedload transport and streamflow at the Ventura River near Ventura and at San Antonio Creek at Casitas Springs. These relations were then applied to existing records of average daily streamflow to estimate coarse-suspended-sediment load and bedload for the periods of sediment-data collection.

Ventura River Near Ventura (11118500)

To estimate bedload for the Ventura River near Ventura (11118500), an average-bedload-transport curve (fig. 2) was developed for the entire period of record. This curve is based on both direct measurements of bedload transport using methods described by Helley and Smith (1971) and calculated values determined with the Meyer-Peter and Muller bedload formula using the modifications of the U.S. Bureau of Reclamation (1960). Input data required for this formula are:

1. Instantaneous water discharge;

2. Width and average depth of stream cross section;

3. Water-surface slope;

4. Roughness factors (Manning roughness coefficient, $n$ ) for bed and banks; and

5. Bed material particle-size distribution.

The hydraulic data needed for the calculations were obtained from streamflow measurements. A composite bed-material sample (table 3) was used for particle-size distribution. No correction was applied to the optical and particle-count data, following the method of Kellerhals and Bray (1971) who found that those types of data are equivalent. This sample was believed to more accurately represent average conditions over the period of record than individual samples, and was used in all calculations. Use of this composite sample resulted in discrepancies with previously published values of bedload discharge (U.S. Geological Survey, 1972-75b, 1974a, 1974b, 1976-82). Daily values of bedload discharge were obtained for the period of record by using the bedload-transport curve to estimate average bedload corresponding to average daily streamflows. Daily values were summed to obtain annual values.

To estimate coarse-suspended-sediment discharge, a relation was determined between streamflow and the percentage of suspended sediment, by weight, that was $0.062 \mathrm{~mm}$ in diameter or larger. This relation was based on all existing size analyses for suspended-sediment samples collected at instantaneous streamflow of at least $100 \mathrm{ft}^{3} / \mathrm{s}$. Samples collected at lower streamflows were not used because the great scatter of the data points would result in decreased accuracy at higher flows, which are most important for sediment transport, as discussed below. First, values for instantaneous streamflow and suspended-sediment concentration were log-transformed, and a relation between the transformed values was determined by linear regression. The resulting equation is:

$$
\log C_{T}=1.12+0.754 \log Q
$$


where $C_{T}$ is the concentration of total-suspended sediment, in milligrams per liter, and $Q$ is instantaneous streamflow, in cubic feet per second. The $r^{2}$ value for this regression is 0.70 , adjusted for degrees of freedom. The concentrations of coarse-suspended sediment were obtained by multiplying the percentage of coarse material in each sample by the concentration of total-suspended sediment $\left(C_{T}\right)$. These values were then $10 g-t$ ransformed, and a second equation was determined by linear regression:

$$
\log C_{C}=-1.88+1.38 \log Q \text {, }
$$

where $C$ is the concentration of coarse-suspended sediment. The $r^{2}$ value for this regression is 0.75 , adjusted for degrees of freedom. Both regression lines and all data points used to derive them are shown in figure 3 . Data points representing samples collected at streamflows less than $100 \mathrm{ft} / \mathrm{s}$ also are included. A range of values of $\log Q$ was selected, and corresponding values for $\log C_{T}$ and $\log C_{C}$ were determined from equations 1 and 2 . The antilogs for these values were then used to compute the percentage of coarse material for the selected values of $\log Q$. The resulting relation is:

$$
\log \% S A N D=-3.00+0.626 \log Q \text { or } \% \text { SAND }=0.001 Q^{0.626} \text {, }
$$

where \%SAND is the percentage of coarse material in the suspended-sediment load. Equation 3 was used to determine the percentage of coarse-suspended sediment for all average daily values of suspended-sediment discharge using 1 log-transformed values of average daily streamflow for $\log Q$. Values of daily streamflow below $100 \mathrm{ft}^{3} / \mathrm{s}$ were included, as the wide scatter of the size data at low flows precluded defining any more accurate relation. Resulting errors are believed to be minor because only a small fraction of the annual sediment load is transported at low flows, as discussed below. Daily values were summed to give annual totals.

Estimates of total coarse-sediment load were calculated as coarsesuspended-sediment load plus bedload. Estimates of total-sediment load were calculated as the sums of suspended-sediment load and bedload. These estimates may misrepresent the actual coarse- and total-sediment loads because sediment concentrations, particularly concentrations of coarse-size fractions, are often not uniform with depth (Colby, 1956). Concentrations of suspended sediment determined from suspended-sediment samples may not, therefore, be representative of suspended-sediment concentrations below the sampled zone, that is, from the surface of the stream bed to 0.3 foot above the bed (Colby, 1963). Bedload samples collected using the method of Helley and Smith (1971) also may fail to adequately represent sediment transport near the bed because the normal mesh size used with the bedload sampler, $0.2 \mathrm{~mm}$, allows finer particles to escape. Consequences of these sampling problems for determining sediment loads are discussed by Hubbell (1964). 


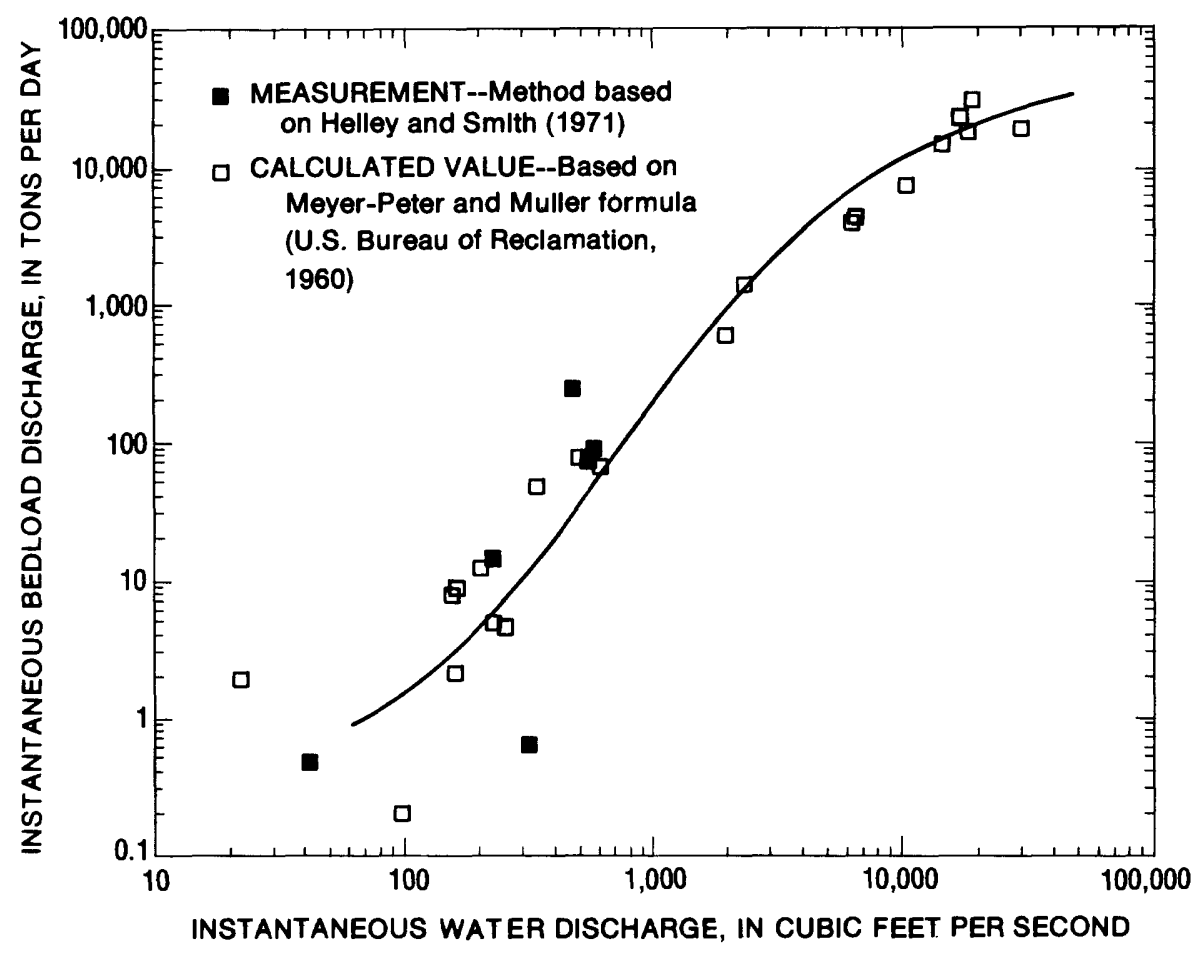

FIGURE 2.--Bedload-transport curve, Ventura River near Vèntura (11118500).

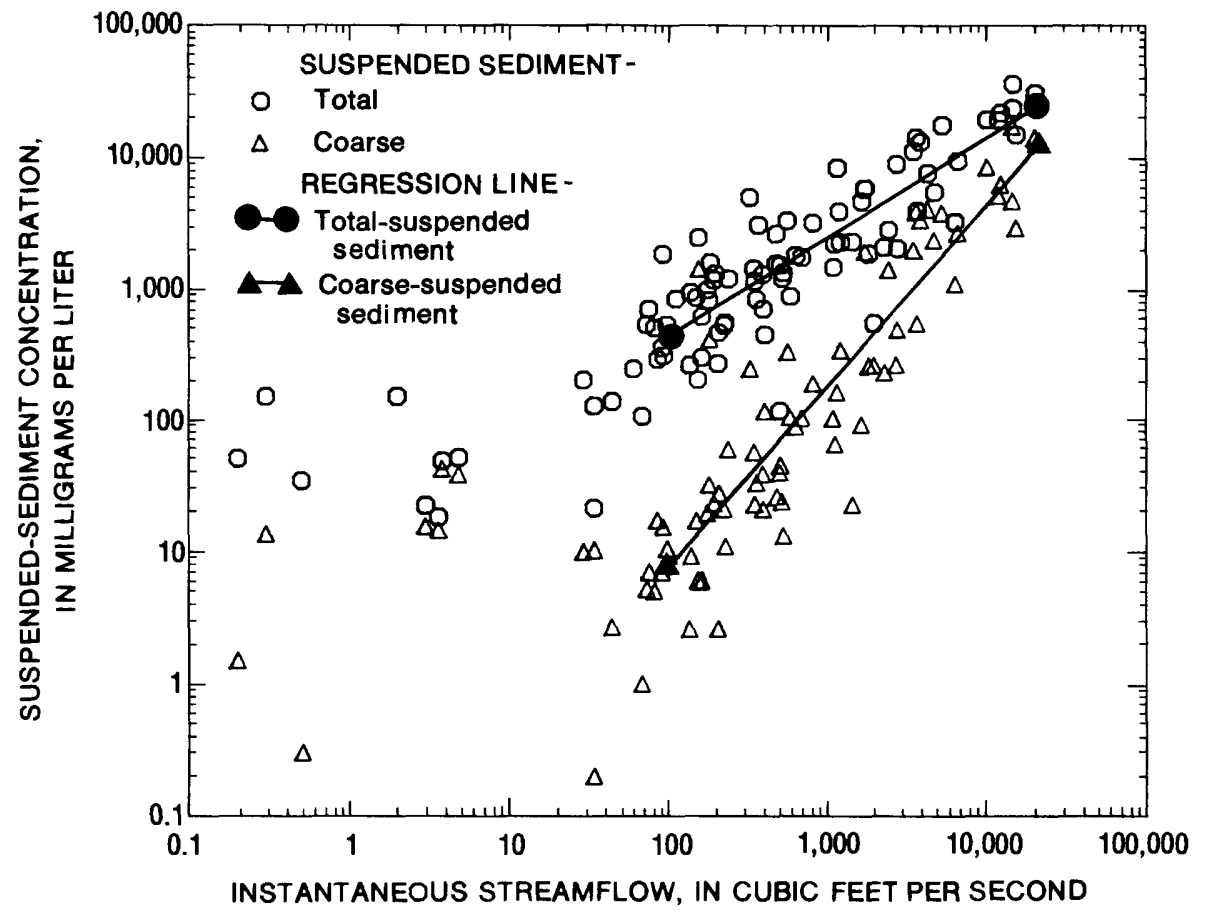

FIGURE 3.--Concentration curves for total-suspended and coarse-suspended sediment, Ventura River near Ventura (11118500). 


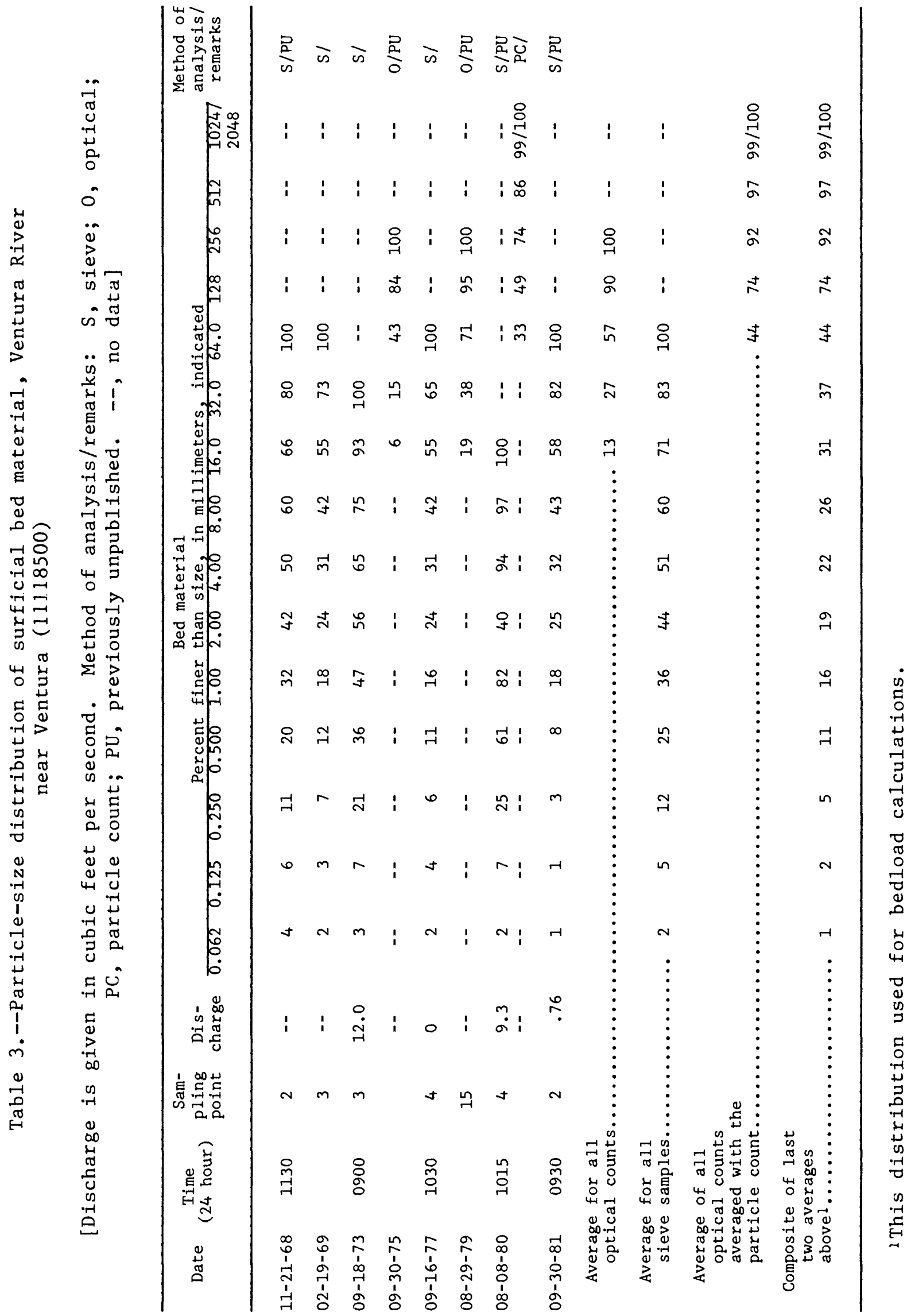




\section{San Antonio Creek at Casitas Springs (11117500)}

Bedload discharge and coarse-suspended-sediment discharge for the San Antonio Creek at Casitas Springs were calculated using the methods described previously. A single bed-material sample was used for the bedload calculations using the Meyer-Peter and Muller method (U.S. Bureau of Reclamation, 1960). The size distribution of this sample is shown in table 4. Direct measurements of bedload transport using the Helley and Smith (1971) method as well as values calculated with the Meyer-Peter and Muller formula (U.S. Bureau of Reclamation, 1960) were used to develop the bedload-transport curve shown in figure 4. Use of the Meyer-Peter and Muller calculation allowed extension of the bedload-transport curve to the high flows of 1978; values obtained from this curve are therefore probably more accurate than values published previously by the U.S. Geological Survey (1976-82).

Only 15 suspended-sediment size analyses were available for station 11117500 , and of these, only 6 were from samples collected at or above 100 $\mathrm{ft}^{3} / \mathrm{s}$. These six analyses were used to develop relations between streamflow and concentrations of total- and coarse-suspended sediment. The resulting equations are:

and

$$
\begin{aligned}
& \log C_{T}=1.04+0.922 \log Q\left(r^{2}=0.93\right) \\
& \log C_{C}=-2.09+1.68 \log Q\left(r^{2}=0.73\right),
\end{aligned}
$$

where $C_{T}, C_{C}, Q$, and $r^{2}$ are as defined in equations $1-3$. From equations 4 and 5, the resulting relation for percentage of coarse material in suspended sediment (\%SAND) is:

$$
\log \% \text { SAND }=-3.13+0.758 \log Q \text { or } \% \text { SAND }=0.00074 Q^{0.758} \text {. }
$$

Equation 6 was used to determine the percentage of coarse material in the suspended-sediment load in the same manner as used for the Ventura River. Estimates of total coarse-sediment load were calculated as coarse-suspendedsediment load plus bedload. Estimates of total-sediment load were calculated as the sums of suspended-sediment load and bedload. The concentration curves for total-suspended sediment and coarse-suspended sediment are shown in figure 5 . 

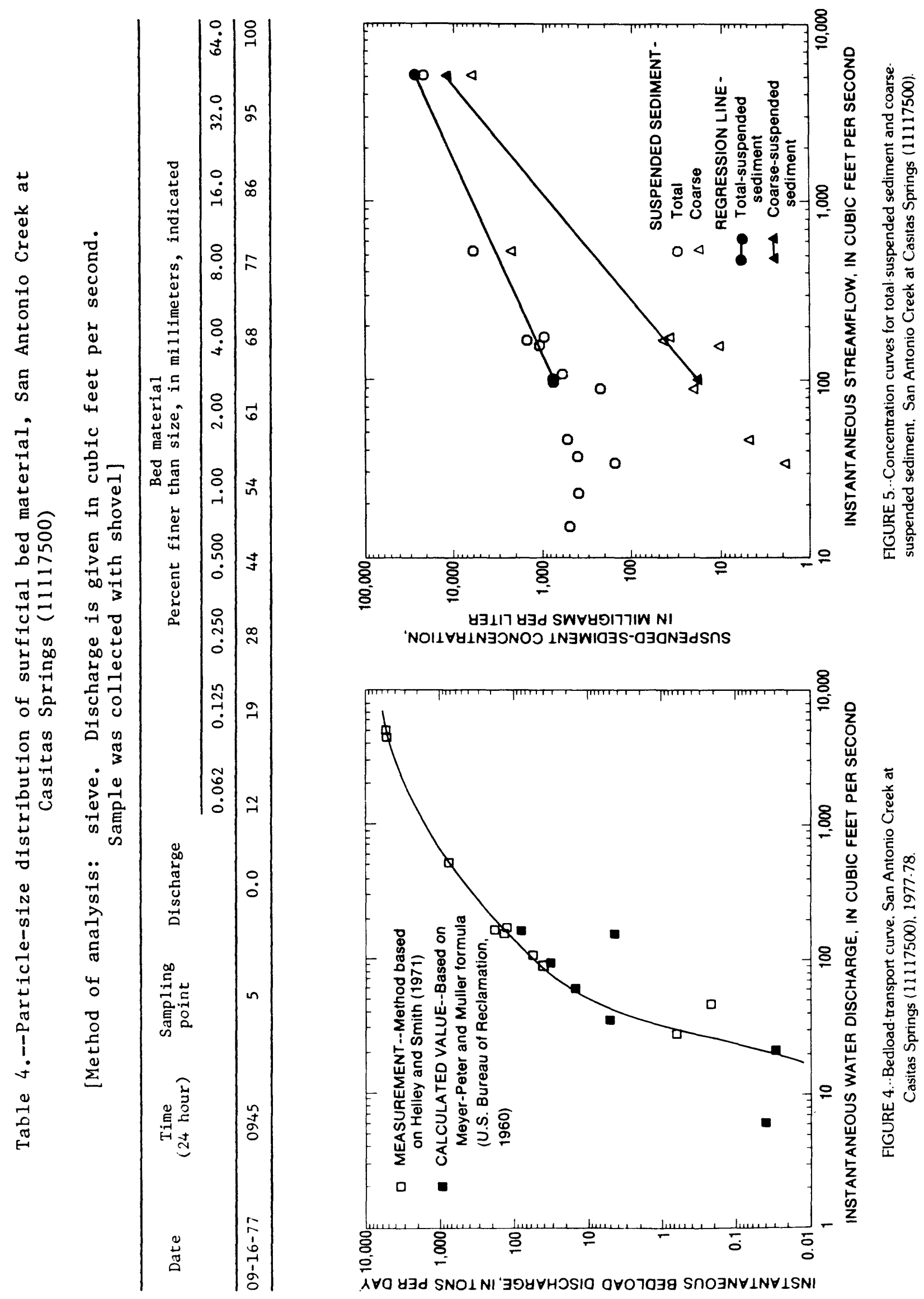


\title{
Ventura River Coarse-Sediment Transport
}

\begin{abstract}
Percentages of coarse sediment in suspended sediment and in total sediment, percentage of bedload in total sediment, and total-sediment yield for the Ventura River near Ventura during the period of data collection are given in table 5. During the 12 years of sediment-data collection, more than 98 percent of the sediment was transported as suspended sediment and less than 2 percent as bedload. Of the total-sediment transport, 40 percent consisted of coarse particles potentially available for replenishment of beach sand. of this coarse fraction, 96 percent was moved as suspended sediment, and the remainder as bedload. All the coarse-suspended sediment was within the sand-size range $(0.062$ to $2.00 \mathrm{~mm})$. Particles transported as bedload ranged from silt to gravel size (less than 0.062 to greater than $32 \mathrm{~mm}$ ).
\end{abstract}

The relation of coarse-suspended-sediment concentration to streamflow is not well defined for the Ventura River. This is apparent from the relatively low value of the correlation coefficient for equation 2 as well as from the scatter of the data points plotted in figure 3. Factors other than the magnitude of streamflow evidently are important in determining the variability of coarse-suspended-sediment concentration. Until these factors are better understood, however, relations such as those defined by equations 1-3 will provide the most reasonable means of estimating the transport of coarse-suspended sediment.

The relation between streamflow and the percentage of coarse material in suspended sediment indicates that at higher flows a larger proportion of the suspended load will consist of coarse sediment. Thus, as shown in table 4, high annual streamflows will not only result in high sediment loads, but those loads will contain greater percentages of coarse sediment. The implications of this relation are considered further in the section "Effects of Major Storms."

$\frac{\text { Comparison of Ventura River Near Ventura and San Antonio Creek }}{\text { at Casitas Springs }}$

The water years during which sediment data were collected on San Antonio Creek at Casitas Springs represent hydrologic extremes, with 1977 being the second of two drought years and 1978 being a year of exceptionally high streamflow (tables 5 and 6 ). Both streamflow and the suspended-sediment load were higher at San Antonio Creek (station 11117500) than at the Ventura River (station 11118500) during the dry year of 1977, presumably because of seepage losses into the streambed between the two stations. During 1978, streamflow at the Ventura River station exceeded that at the San Antonio Creek station by over four times, but the total-sediment load was only twice as great at the Ventura River station. These results suggest that channel aggradation may occur along San Antonio Creek during dry years, but that during years of high flow, its contribution of suspended sediment to the Ventura River is proportionately greater than its contribution of streamflow. 


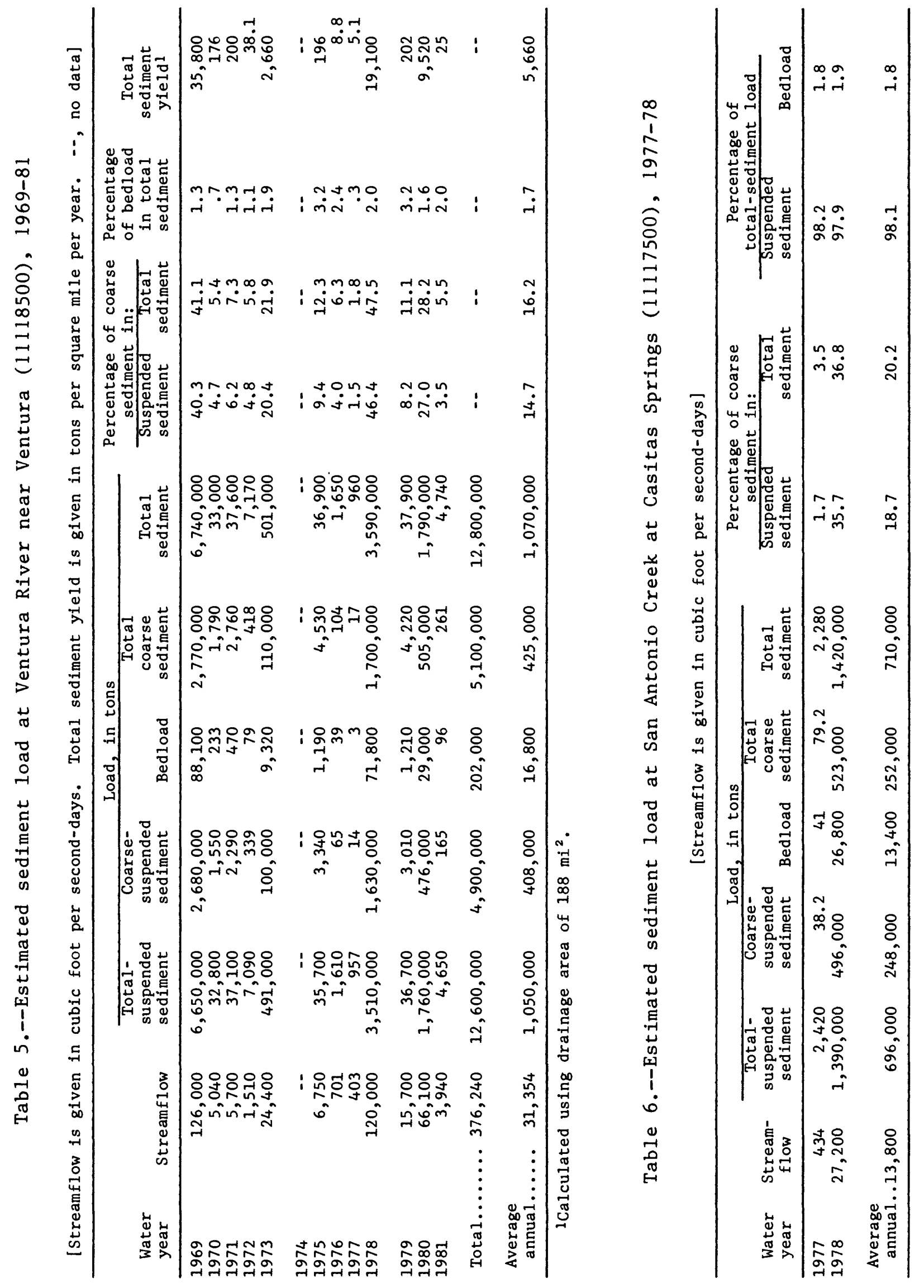


The San Antonio Creek basin constitutes 27 percent of the drainage area of the Ventura River at station 11118500. During 1977-78, San Antonio Creek contributed 23 percent of the streamflow, 40 percent of the total sediment load, and 31 percent of the coarse-sediment load to the Ventura River near Ventura. These percentages indicate that the undeveloped San Antonio Creek basin contributes slightly less streamflow but more coarse and total sediment per unit area than the regulated parts of the Ventura basin. The average-annual total sediment yield for water years 1977 and 1978 was 9,550 $\left(\right.$ ton $\left./ \mathrm{mi}^{2}\right) / \mathrm{yr}$ for the Ventura River near Ventura (table 5) and 13,900 (ton $/ \mathrm{mi}^{2}$ )/yr for San Antonio Creek at Casitas Springs. The difference in yields for the two stations reflects, to some degree, the effects of dams and diversions on the Ventura River and its tributaries, as part of the sediment delivered to reservoirs is retained (Scott and others, 1968) and is not transported further downstream.

A more realistic value for the actual sediment yield of the entire Ventura River basin can be calculated by considering the trap efficiencies of reservoirs in the basin. Trap efficiencies for reservoirs in the Ventura River basin, calculated by the storage capacity-watershed area method (Brune, 1953), are given in table 1. These trap efficiencies were used to calculate effective drainage areas for regulated portions of the basin using the formula:

$$
D A_{\text {effective }}=(1-T E / 100) \times D A \text { regulated },
$$

where $D A$ effective and $D A$ regulated represent the effective and actual drainage areas, in square miles, above dams, respectively, and $T E$ is trap efficiency, in percent. The effective drainage areas were summed and added to the area of the unregulated parts of the basin. This total effective drainage area was used to calculate an effective total sediment yield of $17,200\left(\mathrm{ton} / \mathrm{mi}^{2}\right) / \mathrm{yr}$ by dividing the average-annual total sediment load for 1977-78 at station 11118500 by the total effective drainage area. This figure is an estimate of what the actual sediment yield would have been at station 11118500 for 1977-78 had no sediment been deposited behind dams.

If both the drainage area and the total sediment load for San Antonio Creek are subtracted from the total drainage area and sediment load, respectively, at station 11118500 , the resulting sediment yield for the Ventura basin, exclusive of the San Antonio Creek basin, for 1977-78 was 7,910 $\left(\right.$ ton $/ \mathrm{mi}^{2}$ )/yr. If, however, the effective drainage area exclusive of the San Antonio basin is used in the above calculation, the resulting sediment yield for this area becomes $20,300\left(\operatorname{ton} / \mathrm{mi}^{2}\right) / \mathrm{yr}$. This figure probably represents a more accurate estimate of the actual production of sediment per unit area in the parts of the basin outside the San Antonio Creek basin than does the sediment yield calculated using the total drainage area and total sediment load. Thus, although the sediment yield during 1977-78 was higher for the San Antonio Creek basin than for the rest of the Ventura basin under existing conditions of flow regulation, the actual production of sediment per unit area seems to be highest in areas other than the San Antonio Creek basin. These include the areas downstream of Matilija and Casitas Reservoirs. With the available data, it is not possible to determine the relative importance of the areas downstream from dams as sources of sediment; however, in other areas, channel erosion has increased along reaches below dams due to release of relatively sediment-free water into the channels (Williams and Wolman, 1984; Andrews, 1986). 
Records of the Casitas Municipal Water District indicate that an estimated 63,000 $\mathrm{yd}^{3}$ of sediment were removed from the Robles-Casitas stilling basin after the 1969 flood, and that estimated volumes of $50,000 \mathrm{yd}^{3}$ and $91,000 \mathrm{yd}^{3}$ were removed in 1973 and 1978, respectively. Photographs of this material show that it included many large boulders, but the actual particle-size distribution is not known. It is unlikely that much coarse sediment was transported through Matilija Reservoir. Thus, most of this coarse sediment must have been supplied by a relatively small area drained by unregulated tributaries and by channel erosion between Matilija Dam and the stilling basin. These observations support the contention that these areas may be significant sediment sources.

\section{Effects of Major Storms}

Major storms affected the Ventura basin in 1969, 1978, and 1980 . Streamflow, total-suspended-sediment load, and coarse-suspended-sediment load for five major storm periods during these years are given in table 7 , along with percentages of annual total-suspended-sediment and coarsesuspended-sediment load represented by each storm. In each of the three years considered, over 98 percent of the coarse-suspended sediment and over 96 percent of the total-suspended sediment were transported during one or two storm periods lasting an average of 10 days each. The storm-period sediment loads given in table 7 represent 92 percent of the total-suspended-sediment load and 97 percent of the coarse-suspended-sediment load for the entire period of data collection. The relatively infrequent long-duration, highintensity storm events, therefore, dominate the movement of sediment from the Ventura basin to the ocean.

Table 7.--Sediment transport at Ventura River near Ventura (11118500) during major storm periods, 1969-81

[Streamflow is given in cubic foot per second-days]

\begin{tabular}{|c|c|c|c|c|c|c|}
\hline $\begin{array}{l}\text { Storm } \\
\text { period }\end{array}$ & $\begin{array}{l}\text { Stream- } \\
\text { flow } \\
\text { (Q) }\end{array}$ & $\begin{array}{c}\text { Load, } \\
\text { Total- } \\
\text { suspended- } \\
\text { sediment } \\
\left(Q_{\mathrm{SS}}\right)\end{array}$ & $\begin{array}{l}\text { tons } \\
\text { Coarse- } \\
\text { suspended- } \\
\text { sediment } \\
\left(Q_{c s s}\right)\end{array}$ & $\begin{array}{l}\text { Percentage } \\
\text { of annual } \\
\text { coarse- } \\
\text { suspended- } \\
\text { sediment } \\
\text { load }\end{array}$ & $\begin{array}{l}\text { Percentage } \\
\text { of annual } \\
\text { suspended- } \\
\text { sediment } \\
\text { load }\end{array}$ & $\begin{array}{c}\text { Ratio of } \\
\text { suspended- } \\
\text { sediment } \\
\text { load to } \\
\text { streamflow } \\
\left(Q_{S S} / Q\right)\end{array}$ \\
\hline $\begin{array}{l}\frac{1969}{J a n} \cdot 19-29 \\
\text { Feb. } 23-27\end{array}$ & $\begin{array}{c}56,100 \\
40,300 \\
\text { Total.... }\end{array}$ & $\begin{array}{r}3,650,000 \\
2,860,000 \\
\ldots \ldots \ldots \ldots\end{array}$ & $\begin{array}{l}1,520,000 \\
1,170,000 \\
\ldots \ldots \ldots \ldots\end{array}$ & $\begin{array}{r}56.7 \\
43.7 \\
1100.4\end{array}$ & $\begin{array}{l}54.9 \\
43.0 \\
97.9\end{array}$ & $\begin{array}{l}65.1 \\
71.0\end{array}$ \\
\hline $\begin{array}{l}\text { Feb. } \frac{1978}{5-15} \\
\text { Mar. } 1-6\end{array}$ & $\begin{array}{r}45,800 \\
30,900 \\
\text { Total..... }\end{array}$ & $\begin{array}{r}2,080,000 \\
1,300,000 \\
\ldots \ldots \ldots\end{array}$ & $\begin{array}{r}1,040,000 \\
568,000 \\
\ldots \ldots \ldots\end{array}$ & $\begin{array}{r}63.8 \\
34.8 \\
\ldots \quad 98.7\end{array}$ & $\begin{array}{l}59.3 \\
37.0 \\
96.3\end{array}$ & $\begin{array}{l}45.4 \\
42.1\end{array}$ \\
\hline Feb $\frac{1980}{14-24}$ & 36,200 & $1,740,000$ & 475,000 & 99.8 & 98.9 & 48.1 \\
\hline
\end{tabular}

1Exceeds 100 percent due to rounding of values. 
Scott and Williams (1978) suggested that after sediment is flushed from the channel system during a major flood, sediment-transport rates will be lowered because of removal of accumulated sediment by high flows. The chronology of storm events may therefore affect the relation of sediment discharge to streamflow during storms because less sediment will be available for storms occurring shortly after preceding storms. Table 7 gives the ratios of suspended-sediment load to streamflow $\left(Q_{S S} / Q\right)$ for each of the five major storm periods listed. The storms of early 1969, the first major storms to affect the region since 1938, have both the highest streamflow total and the highest ratio of suspended-sediment load to streamflow of these storms listed. A decrease in $Q_{S S} / Q$ is apparent for subsequent storms, but because none of these events equaled or exceeded the streamflow of the January 1969 storm, it is unclear whether this decrease can be ascribed to flushing of the channel system in 1969 .

\section{Comparison With Results of Previous Studies}

The only previous study in which sediment loads on the Ventura River were estimated in units of mass is that of Brownlie and Taylor (1981). These authors reported estimates of 827,000 tons of bedload, 2,270,000 tons of coarse sediment, and $8,090,000$ tons of total sediment for the Ventura River (station 11118500) for the period 1969-75, excluding 1974 (a11 estimates rounded to three significant figures). Estimates determined for this report represent 12 percent of the bedload, 127 percent of the coarse-sediment load, and 92 percent of the total-sediment load estimated by Brownlie and Taylor (1981) for this period. The large discrepancy in the bedload estimates may result from differences in methods of analysis. The use of the modified Einstein formula (Burkham and others, 1977) by Brownlie and Taylor (1981) is a possible cause for the higher estimate of these authors. As shown in table 2, bed material of the Ventura River is composed largely of gravel- and cobble-size particles. The modified Einstein procedure used by Brownlie and Taylor has been tested only on sand-size sediments (Burkham and Dawdy, 1980), and its accuracy for other size classes has not been established. As noted by Williams (1979), the Meyer-Peter and Muller formula is generally the accepted method for coarse-bed streams.

To permit comparisons with results given in volumes of sediment per unit time in other studies, the annual total-sediment loads at station 11118500 were converted to acre-feet per square mile per year using the total drainage area above the gage and an estimated value of $94 \mathrm{lb} / \mathrm{ft}^{3}$ for sediment bulk density. This density value represents a reasonable estimate for geologic materials. Use of this estimate results in a mean estimated yield of 2.78 $\left(\right.$ acre-ft/mi $\left./ \mathrm{m}^{2}\right) / \mathrm{yr}$. This result agrees reasonably well with results of Scott and Williams (1978) and Taylor (1981, 1983), but is an order of magnitude greater than those of the California Department of Navigation and Ocean Development (1977). 
At the Ventura River near Ventura during the period 1969-81, excluding 1974, total-sediment load was $12,800,000$ tons. Of this total, 5,100,000 tons, or 40 percent, was composed of coarse particles potentially available for replenishment of beach sand. Suspended-sediment load constituted 12,600,000 tons, of which 4,900,000 tons was coarse sediment. Suspended-sediment transport was therefore the most important process moving sediment to the coast, supplying 98 . percent of the total-sediment load and 96 percent of the coarse-sediment load. Bedload transport contributed less than 2 percent of the total-sediment load and less than 4 percent of the coarse-sediment load. The proportion of coarse sediment in the suspended-sediment load was directly related to streamflow; thus high flows contribute proportionately more coarse sediment than do lower flows.

Results of this study agree closely with results published by earlier investigations. Differences in methods of analysis probably account for discrepancies in estimates of bedload.

The unregulated San Antonio basin contributes more sediment per unit of total basin area than do the regulated parts of the Ventura basin, as would be expected from consideration of the sediment-trapping properties of reservoirs. Comparison of sediment loads on the Ventura River near Ventura and San Antonio Creek as Casitas Springs, however, indicates that because only a fraction of the sediment supplied to the channel system upstream from the reservoirs can be expected to be transported to reaches downstream from the dams, the actual sediment production per unit area is lower in the unregulated San Antonio Creek basin than in the rest of the Ventura basin. This may be in part the result of the discharge of sediment-free water to channels downstream from dams.

Major storm events dominate sediment transport. Infrequent highintensity rainstorms resulted in 93 percent of the annual total-suspendedsediment load and 98 percent of the coarse-suspended-sediment load for the period of data collection. The chronology of storm events may exert some influence over storm-sediment transport, as sediment removed rapidly from channels during high flows is gradually replenished by hillslope processes. 


\section{REFERENCES CITED}

Anderson, H.W., Coleman, G.B., and Zinke, P.S., 1959, Summer slides and winter scour, dry-wet erosion in southern California mountains: U.S. Forest Service, Pacific Southwest Forest and Range Experiment Station, Technical Paper $36,12 \mathrm{p}$.

Andrews, E.D., 1986, Downstream effects of Flaming Gorge Reservoir on the Green River, Colorado and Utah: Bulletin of the Geological Society of America, v. 97, no. 8, p. 1012-1023.

Brownlie, W.R., and Taylor, B.D., 1981, Coastal sediment delivery by major rivers in southern California: California Institute of Technology, Environmental Quality Laboratory, EQL Report No. 17-C, 314 p.

Brune, G.M., 1953, Trap efficiency of reservoirs: American Geophysical Union Transactions, v. 34, p. 407-418.

Burkham, D.E., and Dawdy, O.E., 1980, General study of the modified Einstein method of computing total sediment discharge: U.S. Geological Survey Water-Supply Paper 2066, 67 p.

Burkham, D.E., Kroll, C.G., and Porterfield, George, 1977, A guide for the application of the computer program for the modified Einstein method of computing total sediment discharge (MODEIN): U.S. Geological Survey Computer Contribution, 143 p. [Available only from U.S. Department of Commerce, National Technical Information Service, Springfield, VA 22161 as Report PB 262429/AS.]

California Department of Navigation and Ocean Development, 1977, Study of beach nourishment along the southern California coastline: $151 \mathrm{p}$.

Colby, B.R., 1956, Relationship of sediment discharge to streamflow: U.S. Geological Survey Open-File Report, 170 p.

---- 1963, Fluvial sediments--a summary of source, transportation, deposition, and measurement of sediment discharge: U.S. Geological Survey Bulletin 1181-A, $47 \mathrm{p}$.

Colby, B.R., and Hembree, C.H., 1955, Computation of total sediment discharge, Niobrara River near Cody, Nebraska: U.S. Geological Survey Water-Supply Paper $1357,187 \mathrm{p}$.

Cooke, R.U., and Reeves, R.W., 1976, Arroyos and environmental change in the American Southwest: Oxford, Clarendon Press, 213 p.

Guy, H.P., 1970, Fluvial sediment concepts: U.S. Geological Survey Techniques of Water-Resources Investigations, Chapter $\mathrm{Cl}$, Book 3, $55 \mathrm{p}$.

Helley, E.J., and Smith, Winche11, 1971, Development and calibration of a pressure difference bedload sampler: U.S. Geological Survey Open-File Report, $18 \mathrm{p}$.

Hubbe11, D.W., 1964, Apparatus and techniques for measuring bedload: U.S. Geological Survey Water-Supply Paper 1748, 74 p.

Kellerhals, Rolf, and Bray, D.J., 1971, Sampling procedures for coarse fluvial sediments: Journal of the Hydraulics Division, Proceedings of the American Society of Civil Engineers, v. 97, no. HY8, p. 1165-1180.

Knott, J.M., 1980, Reconnaissance assessment of erosion and sedimentation in the Cañada de los Alamos basin, Los Angeles and Ventura Counties, California: U.S. Geological Survey Water-Supply Paper 2061, 26 p.

Lustig, L.K., 1965, Sediment yield of the Castaic watershed, western Los Angeles County, California--A quantitative geomorphic approach: U.S. Geological Survey Professional Paper 422-F, 23 p.

Porterfield, George, 1980, Sediment transport of streams tributary to San Francisco, San Pablo, and Suisun Bays, California, 1909-66: U.S. Geological Survey Water-Resources Investigations Report 80-64, 92 p. 
Putnam, W.C., 1942, Geomorphology of the Ventura region, California: Bulletin of the Geological Society of America, v. 53, p. 691-754.

Rantz, S.E., 1969, Mean annual precipitation in the California region: U.S. Geological Survey Open-File Report, 2 map sheets.

Rice, R.M., Gorsline, D.S., and Osborne, R.A., 1976, Relationships between sand input from rivers and the composition of sands from the southern beaches of southern California: Sedimentology, v. 23, p. 689-703.

Scott, K.M., Ritter, J.R., and Knott, J.M., 1968, Sedimentation in the Piru Creek watershed, southern California: U.S. Geological Survey Water-Supply Paper 1798-E, 48 p.

Scott, K.M., and Williams R.P., 1978, Erosion and sediment yields in the Transverse Ranges, southern California: U.S. Geological Survey Professional Paper 1030, 38 p.

Shiller, G.I., 1972, Suspension in selected streams of the southern California Bight and the flood of 1969: Los Angeles, University of Southern California, Report no. USC Geology 72-3, 69 p.

Taylor, B.D., 1981, Inland sediment movements by natural processes: California Institute of Technology, Environmental Quality Laboratory, EQL Report no. 17-B, 81 p.

---- 1983, Sediment yields in coastal southern California: Journal of Hydraulic Engineering, v. 109, no. 1, p. 71-85.

U.S. Bureau of Reclamation, 1954, Ventura River project, California--a report on the feasibility of water supply development: $210 \mathrm{p}$. and appendixes.

---- 1960, Investigation of Meyer-Peter and Muller bedload formulas: $22 \mathrm{p}$.

U.S. Geological Survey, 1972-75a, Water resources data for California, water years 1971-74; Part 1, surface water records; Volume 1: Colorado River basin, southern Great Basin, and Pacific slope basins excluding Central Valley: U.S. Geological Survey Water-Data Reports CA-71-1 to CA-74-1, published annually.

- 1972-75b, Water resources data for California, water years 1971-74; Part 2, water quality records: U.S. Geological Survey Water-Data Reports CA-7I-3 to CA-74-3, published annually.

---- 1974a, Quality of surface waters of the United States, 1969; Part 11, Pacific slope basins in California: U.S. Geological Survey Water-Supply Paper 2149,349 p.

-- 1974b, Quality of surface waters of the United States, 1970; Part 11, Pacific slope basins in California: U.S. Geological Survey Water-Supply Paper 2159,397 p.

---- 1976, Surface water supply of the United States, 1966-70; Part 11, Pacific slope basins in California; Volume 1, Basins from Tijuana River to Santa Maria River: U.S. Geological Survey Water-Supply Paper 2128, $552 \mathrm{p}$.

-.-- 1976-82, Water resources data for California, water years 1975-81; Volume 1: Colorado River basin, southern Great Basin from Mexican border to Mono Lake basin, and Pacific slope basins from Tijuana River to Santa Maria River: U.S. Geologica1 Survey Water-Data Reports CA-75-1 to CA-81-1, published annually.

---- 1977, National handbook of recommended methods for water-data acquisition: Reston, Virginia, pagination variable--looseleaf format for updates.

--- 1986 [1987], Water Resources Division publications guide, volume 1: Publications policy and text preparation: U.S. Geological Survey Open-File Report 87-205, 429 p. 
Wells, W.G., and Palmer, N.R., 1982, Role of vegetation in sediment processes of coastal southern California, in Special inland studies: California Institute of Technology, Environmental Quality Laboratory, EQL Report no. $17-\mathrm{D}, \mathrm{P} .51-82$.

Williams, R.P., 1979, Sediment discharge in the Santa Clara River basin, Ventura and Los Angeles Counties, California: U.S. Geological Survey Water-Resources Investigations Report 79-78, $51 \mathrm{p}$.

Williams, G.P., and Wolman, M.G., 1984, Downstream effects of dams on alluvial rivers: U.S. Geological Survey Professional Paper 1286, 83 p. 